\title{
CAPTURE OF FISCAL TRANSFERS: A STUDY OF BRAZILIAN LOCAL GOVERNMENTS*
}

Marcos Mendes $\$$

\begin{abstract}
RESUMO
O artigo analisa um problema observado nas relações fiscais entre entes de uma federação: a captura, por grupos de interesse, das transferências recebidas por governos locais. Quatro hipóteses estabelecidas pela literatura são testadas: a captura cresce com o aumento do grau de ilusão fiscal, com a redução do poder de barganha do eleitor, nos governos locais sobrefinanciados e com a elevação da pobreza local. Os testes empíricos usam dados dos municípios brasileiros. Os resultados econométricos são coerentes com as hipóteses estabelecidas pela literatura e indicam caminhos para a prevenção da captura quando do desenho do sistema de transferências intergovernamentais.
\end{abstract}

Palavras-chave: federalismo fiscal, captura, transferências intergovernamentais, governo local, municípios brasileiros, legislativo.

\begin{abstract}
This paper deals with a problem observed in federal fiscal relations: the capture of transfers received by local interest groups. Four hypotheses established in the literature are tested: capture is expected to increase with fiscal illusion, low bargaining power of the voter, over-financing of some local governments, and degree of poverty. The empirical tests use data from Brazilian local governments. The econometric results are coherent with the hypotheses and give hints on how to prevent capture when designing an intergovernmental transfer system.
\end{abstract}

Key words: fiscal federalism, capture, intergovernamental transfers, local governments, Brazilian municipalities, legislative.

JEL classification: H77, P16, C21, C31.

\footnotetext{
The author acknowledges Fabiana Rocha, Reynaldo Fernandes, Siegfried Bender, Sérgio Guimarães, Maria da Conceição Sampaio, João Ricardo Faria, Francisco Galrão, José Roberto Afonso, David Samuels and the two anonymous referees for their important comments on this paper.

$\S$ Doctor, Economist at Brazilian Federal Senate.

Recebido em agosto de 2004. Aceito em março de 2005.
} 


\section{"The city receives so much money that the politicians create many ways to dissipate it"}

\section{INTRODUCTION}

Fiscal transfers from central to local governments are an important aspect of the design of fiscal relations in a federal system. ${ }^{2}$ They have come up as an important solution to deal with unequal fiscal capacities among the members of a federation as well as to correct externalities. Nevertheless, the positive empirical literature has identified some undesirable effects of transfers. One of these effects, studied in this paper, is the capture of fiscal transfers by local government politicians and bureaucrats. ${ }^{3}$

Four propositions were established by political economy theory where the intergovernmental transfers appear as an incentive for the capture of intergovernamental transfers by local politicians and bureaucrats: fiscal illusion (Strumpf, 1998); low bargaining power of the voter (Wyckoff, 1988); over-financing of some local governments (Inman and Rubinfeld, 1996 and 1997); and a direct relation between capture and local degree of poverty (Bardhan and Mookerjee, 2000; Reinikka and Svensson, 2004) .

This paper tests these four hypotheses. The empirical tests are performed for the Brazilian municipalities. Brazilian federalism exhibits some characteristics that have made it prone to capture. ${ }^{4}$ It is a quite decentralized federation in which the local governments (municipalities) have ample administrative attributions and have revenues that correspond to $6 \%$ of the GDP at their disposal. The country also exceedingly uses the instrument of intergovernmental transfers to finance its subnational governments, which makes room for the capture of these transfers. Different kinds of transfers are used, subject to different levels of fiscal illusion or of voter bargaining power. This allows better identification of the relationship between transfers and capture.

The variable chosen as proxy for capture is the expenditure of the local city councils because some characteristics of the Brazilian political system stimulate rent seeking behavior by the bureaucrats and politicians of the legislature: legislators are not directly responsible for the maintenance of the government fiscal balance which is an executive task. The legislatures at the federal, state and municipal levels have a constitutional protection against fund cuts. The financial autonomy and restricted responsibility for fiscal sustainability, together with the great political power granted by the legislative veto power over executive proposals, assure significant funds to the legislatures, which tend to be used with political criteria. Election campaigns in Brazil are very expensive and the legislators need to ensure funds to finance reelection, as the political parties are not able to provide money to all their candidates. Party funds are usually used to finance campaigns for offices in the executive branch. Therefore, capture may be used as a campaign-funding device.

The econometric results presented in the paper are in line with all four hypotheses tested.

The contributions of this paper are the following. First, the paper shows that capture is more intense in poorer areas. This fact is a challenge to policy makers devoted to poverty reduction poli-

1 (Roberto Lima, former Secretary of Public Administration of the small town of Guamaré, Rio Grande do Norte, explaining why mayors of towns that receive royalties from the federal oil agency decide to sponsor private football teams). (Folha de S. Paulo, 16/ 01/2005: "Football pours over petrol")

2 See, for example, Alm (1983), Bird (1993), Hemming and Sphan (1997), McLure Jr. (1997), Ter-Minassian (1997), Musgrave (1983).

3 For critical views on the normative literature of fiscal transfers see: Tanzi (1995), Prud'homme (1995) and Hommes (1995).

4 Rezende (1995), Afonso and Melo (2000), Giambiagi e Além (2001), Mendes (2002) and Resende (2003) make a quite complete and complementary description of the fiscal federalism in Brazil. 
cies in a federal country, since these policies (public education and health, food stamps, job training etc.) are usually delivered by local governments with federal funds. If capture of the money transferred to local governments is more intense in poorer areas, decentralized poverty reduction policies will be less effective exactly in the regions where they are most needed. It is necessary to be concerned with capture when designing the financing and delivery mechanisms of those policies. Pumping money into poor town budgets is not a sufficient condition to reduce poverty.

Second, it is shown that over-financing stimulates capture. This implies that the design of an intergovernamental transfer system must be careful not to give excessive transfers to some groups of municipalities. The case studied in this paper is that of municipalities that receive royalties from the federal oil agency (ANP). The huge amount of money paid to these towns is being spent in exotic "public goods" such as the sponsorship of private football teams, as shown in the quotation at the beginning of this paper.

The two points presented above (over-financing and poverty) are sometimes related, since it is common to think that a good way to reduce poverty in small backward rural areas is to increase the fiscal transfers to those town halls. This may result in a large amount of money in the hands of local politicians, in small communities that do not have scale to offer a wide range of public services. Furthermore, the poor people living in these towns do not have knowledge, ability or money to finance an organization to lobby for the use of public funds on their behalf. The result will probably be the capture of the additional money received by the poor, small towns.

Third, the paper showed that the way the money flows to the municipal treasury determines the degree of capture. Fiscal resources obtained through local taxes are less likely to be captured, while formula based transfers are much more subject to capture. Therefore, in order to reduce capture and improve the effectiveness of public spending, it is important to provide municipalities with technical assistance to improve their tax collection. At the same time, it is necessary to reduce the great participation of formula-based transfers in the local financing, which is a clear feature of low and mid income federations, particularly of Brazil.

The rest of this paper is organized as follows. Section 2 describes the literature hypotheses linking fiscal transfers to capture. Section 3 describes the Brazilian system of fiscal transfers and shows why this country represents a suitable environment for testing the hypotheses depicted in section 2. Section 4 explains why legislative expenditure is used as a proxy for capture. Section 5 presents the econometric results, and section 6 contains the conclusions and final comments.

\section{FEDERAL SYSTEMS, TRANSFERS, AND CAPTURE: HYPOTHESES IN THE LITERATURE}

In the 1970s, the empirical literature on public finance ${ }^{5}$ identified the so-called flypaper effect: the elasticity of public expenditure of local governments in response to an increase in lump sum fiscal transfers seems to be higher than the elasticity in response to an equivalent increase in personal income. In a model that uses a representative median voter, the two effects should have the same magnitude because, for the voter, a lump sum transfer represents the same as an increase in his private revenue.

5 Gramlich and Galper (1973), Gramlich (1977). 
One of the explanations for this phenomenon is based on Niskanen's bureaucrat concept. (Niskanen, 1971). ${ }^{6}$ Strumpf (1998) presents a model in which the local ruling politician takes advantage of the median voter's fiscal illusion so as to appropriate part of the received transfers.

In this model there are two kinds of public goods: those that are useful for the voters $(G)$ and those that do not generate benefits for the community, but generate benefits for the politician (D). There is an information asymmetry: the median voter does not know the amount of $\mathrm{D}$ and has only partial knowledge about the received transfers.

If the voters are completely informed, they will not allow any expenditure in type $\mathrm{D}$ goods. Under complete fiscal illusion, voters would be unaware of the transfer, and the politicians would be free to use as much money they wanted to purchase type D goods. (Strumpf, 1998, p. 397). Partial fiscal illusion would result in a mix of type $G$ and $D$ goods acquired by the politicians. Capture is financed by the non-visible part of the transfers.

Another model that points out capture as being the cause of the flypaper effect may be extracted from Wyckoff (1988). In this model there is no fiscal illusion: the voters have perfect perception of the total value of the received transfers. But there is an asymmetry in the bargaining power of the two players: the ruling politician and the median voter. The ruling politician, as in Strumpf (1998), intends to maximize capture (D). But, in this model, the voter can react to the ruling politician's action, by moving to another city.

An increase of lump sum transfers would represent an additional amount of money that would belong to the community and not to the voter. In other words, if the voter decided to move to another city, he would not take with him the (per capita) additional revenue represented by the increase of the transfers. So, the ruling politician would have greater bargaining power in the case of an increase in transfers.

On the other hand, in the case of an increase in private income, it is the voter who has greater bargaining power because if he decides to move to another city, he will take the additional income with him. This difference causes the politician to refrain the expansion of capture when there is an increase in local private income, in order to prevent the voter, upset with this behavior, from leaving the jurisdiction taking his additional income away.

The consequence would be the flypaper effect, with the total expenditure being more elastic to transfer increases than to income increases. ${ }^{7}$

Another hypothesis relating fiscal transfers and capture, not associated to the flypaper effect, is established by Inman and Rubinfeld (1996 and 1997). For them, in practice, the intergovernmental transfers are not designed according to technical criteria, aiming at correcting externalities or imbalances of the federation, as proposed in normative theory. They argue that the decisions of central governments regarding transfer allocation criteria are submitted to political pressures, and this ends up generating the over-financing of some local governments. ${ }^{8}$

Technical difficulties, as well as political interferences, may also cause the criteria for intergovernmental transfers to generate a group of privileged municipalities. As Shah (1994) argues, it is

6 Other explanations were proposed by Hamilton (1986) who argues that the effect comes from a deadweight cost existing in the municipal taxation and by Chernik (1974) and Moffit (1984) for whom the effect is not real, appearing as a result of incorrect econometric specification.

7 In fact, the voter may use reelection as an instrument to control the capture by the politician. However, reelection is far from being a perfect instrument to refrain capture, as shown by Person and Tabellini (2000). Thus, voter's mobility remains as an important source of incumbent control.

8 Some papers show empirical evidence of the inadequacy of the systems of transfers in relation to what is proposed in normative theory, as well as the importance of political variables in the definition of transfers: Grossman (1994), Laband (1986), Oates (1994), Inman (1988). 
not simple to define practical criteria that allow determining the fiscal gap of a local government or the exact subsidy necessary to induce the internalization of spillover effects.

Hence, there is the possibility that transfers lead to the over-financing of some municipalities, inducing them to accomplish expenditures of low benefit-cost relation or to ease the minimization of operational costs. ${ }^{9}$ In this context of "abundance of resources" there would be more possibilities of capture by self-seeking politicians.

A forth hypothesis is put forth by Bardhan and Mookherjee (2000, p. 136-7), who propose that the voter's degree of information is a direct function of his or her socioeconomic situation: "political awareness is closely related to socioeconomic position and education level (...) An increase in the fraction of the population that is poor will accordingly imply a lower fraction of informed voters in the population as a whole. (...)[This explains] why capture increases with illiteracy, poverty, and inequality."

Reinikka and Svensson (2004) make a similar proposition though arguing in a different way. They propose a model in which low income communities cannot incur the costs of an organization to lobby against capture. If only middle and high income communities can react against capture, it becomes a phenomenon with a regressive impact over income distribution.

\section{USING THE BRAZILIAN CASE FOR EMPIRICAL TESTING}

Brazil seems to represent a proper environment for testing the hypotheses depicted above. It is a quite decentralized federation ${ }^{10}$ in which the local governments (municipalities) have ample administrative attributions and have revenues that correspond to $6 \%$ of the GDP at their disposal. ${ }^{11}$ The country also exceedingly uses the instrument of intergovernmental transfers to finance its subnational governments. ${ }^{12}$

Another interesting characteristic of Brazilian federalism is that the two main modalities of transfers received by municipalities - Participation Fund of the Municipalities (FPM) and the sharing of the tax on Service and Goods Circulation (ICMS) - present different characteristics, which allow a better identification of the relationship between transfers and capture. ${ }^{13}$

The ICMS transfers are originated from a value added tax collected by the states. According to the federal constitution, one-fourth of this tax must be transferred to the municipalities, and $75 \%$ of this amount should go to the municipality where the tax was collected (derivation principle). This means that the voter has bargaining power over this part of the ICMS transfer based on the derivation principle because his moving to another municipality will cause a revenue loss by the local government. In addition, the variable on which it is based, the calculation of this transfer installment (added value), is well known by the taxpaying companies, which means that there is low fiscal illusion.

9 Kornai (1986).

10 Rezende (1995), Afonso and Melo (2000), Giambiagi e Além (2001), Mendes (2002) and Rezende (2003) make a quite complete description of the fiscal federalism in Brazil.

11 Sources: National Treasury Department and Brazilian Central Bank.

12 In an international comparison, according to the IMF's Government Finance Statistics Yearbook, the tax revenue of the Brazilian municipalities represents only $18 \%$ of the total revenue, while the transfers are responsible for $62 \%$. In $73 \%$ of the Brazilian municipalities, the current transfers account for more than $85 \%$ of the current revenue. In other countries of Latin America, such as Colombia, Bolivia, and Chile, the municipal tax revenue is more representative, surpassing $30 \%$. In developed federal countries such as the USA, Canada, and Australia, tax collection at the local government level are also responsible for more than $30 \%$ of the revenues.

13 Municipal governments may also receive "negotiated transfers", that is, transfers obtained through political negotiations. This kind of transfer may also be subjected to capture. However, it is not possible to consider this kind of transfer in an econometric study, since it is not exogenously determined, as an explanatory variable should be. For instance, a local government whose bureaucracy and politicians are more prone to capturing fiscal transfers would, probably, be more active in obtaining "negotiated transfers". Therefore, the causal relation would be from the capture propensity to the transfers obtained, and the causal relation that the paper intends to identify is from the transfer obtained to the capture. 
On the other hand, the FPM comes from the federal collection and is distributed according to criteria pre-established in law. Because the transfers are from taxes collected all over the country, and not only in the community, it becomes difficult for the median voter to estimate the volume of received transfers each month. ${ }^{14}$ With regard to the voter's bargaining power, this also seems to be weaker in the case of the FPM. If the voter decides to move from the municipality, he will not affect the calculation base of the transfers received by his local government. Therefore, the sharing criteria lead to the assumption that the FPM transfers are more subject to capture than the ICMS transfers.

For this reason, it would be expected that the kind of revenue less subject to capture was the local tax revenue (fully known by the median voter and affected by his decisions of moving or staying in the city), followed by revenues from ICMS transfers and, finally, with the greatest propensity to be captured, the revenues from FPM transfers.

Based on the discussion above, we propose the following statistical test of the hypotheses:

$$
D_{i}=\delta+\lambda^{\prime} \cdot X_{i}+\alpha_{1} \cdot \text { TAXREV }_{i}+\alpha_{2} \text { ICMS }_{i}+\alpha_{3} \cdot \text { FPM }_{i}+\alpha_{4} \cdot \text { ROYALTIES }_{i}+\alpha_{5} \cdot \text { LCI }_{i}+\varepsilon_{i}
$$

Where TAXREV is the tax revenue, and ICMS and FPM are respectively the amounts received in each of these modalities of transfers. It is expected, according to the exposed above, that $\alpha_{3}>\alpha_{2}>\alpha_{1}$.

Both the FPM and the ICMS are transfers whose sharing criteria among the municipalities are defined in law and whose resources come from state and federal collection. They are, therefore, exogenous variables. The same does not take place with the tax revenue, which results from the policy of local collection, and may be influenced by the same political features of local politicians that determine the level of capture. For this reason, a system of equations where TAXREV appears as a dependent variable will also be estimated. ${ }^{15}$

In order to test the inverse relation hypothesis between capture and local poverty degree, the Life Conditions Index $(L C I)$ is used. This variable was created by the United Nations and is based on income, revenue, education, infancy, habitation and longevity indicators. ${ }^{16}$ The 1991 LCI was used as an instrument for the LCI in the reference year of the cross-section (1996) so as to avoid problems of endogenous explanatory variable. It is expected that $\alpha_{5}<0$ (higher life condition implies lower capture).

In order to test the hypothesis that over-financing stimulates capture, the ROYALTIES variable is used. It is a dummy variable which attributes value 1 to the municipality which has received royalties, paid by the state oil company Petrobras, equivalent to $40 \%$ or more of its total revenues. Therefore, they are municipalities where this revenue has a great impact on the total availability of resources, at the same time as the oil exploration activity does not generate the necessity of additional public expenditure. ${ }^{17} \alpha_{4}>0$ is expected.

14 The amount transferred is, at first, calculated based on the municipal population, a variable that may be known by the voter without much difficulty. But there are so many exceptions, ceilings and floors, that the distribution ends up in having a high random component. The values transferred to each municipality are available in the National Treasury Secretary website. But it takes time, access to the internet and some intellectual ability for the median voter to know how to obtain and analyze this information.

15 The ICMS and FPM transfers are both lump sum. For this reason, their coefficients are exempt from expressing substitution effects resulting from changes of relative prices caused by the transfers. Therefore, there is no room for the argument of Chernik (1979) and Moffit (1984) that the different elasticities may result from inadequate econometric procedures.

16 United Nations Development Program (UNDP), Institute of Applied Economic Research (IPEA), Brazilian Institute of Geography and Statistics (IBGE) and João Pinheiro Foundation (1998).

17 Oil exploration in Brazil is predominantly done in offshore oil wells with the exploration infrastructure being set up by Petrobrás itself, without the necessity of bulky expenditures by local governments. Because of their fortunate location within the geographic coordinates of the oil exploration areas, they receive royalty payments. The current per capita revenue of the municipal districts that are receivers of royalties is $12 \%$ superior to that of other municipal districts. 


\section{PROXY FOR CAPTURE: THE LEGISLATIVE EXPENDITURE}

In order to estimate (1), it is necessary to have a quantitative measure of the capture. Reinikka and Svensson used the coefficient between transfers effectively received by local schools in Uganda and the total transfer made from the central government to the local government. Their intention was to quantify the amount of money that should have been paid by the local government to the schools but that was captured by local politicians and bureaucrats. It is not possible to use this kind of measurement in the present paper since it would require the implementation of a survey to collect the data, which is beyond the scope of the paper.

Strumpf (1998) uses the administrative costs of the local government (administration, planning, etc.). His idea is that the overhead costs constitute the only expenditure category of the local governments that is not associated with the provision of a well-defined public service, such as urban cleaning or public illumination. So he assumes that "most wasteful spending would be labeled as overhead rather than some more transparent expenditure group." (Strumpf, 1998, p. 399).

In Brazil, the classification of the expenditure is excessively broad. Expenditure in "education" may both represent the purchase of books for elementary schoolsand the purchase of a luxury car to be used by the municipal education secretary. However, there is one of these functions that may constitute an adequate proxy for capture: the legislative expenditure.

The Brazilian legislatures (at federal, state, and municipal levels) are institutions prone to capture. The legislators are not directly responsible for the maintenance of the fiscal balance, a task which is the responsibility of the executive branch. ${ }^{18}$

In addition, the legislatures (and judiciaries) of the three governmental levels possess a protective shield against expenditure control policies. Having the principle of the independence of the branches in mind, the Federal Constitution forbids that the executive branch reduce funds for the legislature and judiciary, in order to prevent the former from trying to influence decisions of the latters by means of financial bargaining. This financial autonomy, together with the great political power granted by the possibility of obstructing executive projects, tend to assure significant funds for the legislatures. ${ }^{19}$

Furthermore, election campaigns in Brazil are very expensive (Samuels, 2000) and the legislators need to ensure funds to finance reelection, since the political parties are not able to supply money to all their candidates. Political party funds are generally used to finance campaigns for office in the executive branch. Therefore, capture may be used as a campaign funding device. (Samuels, 2002).

Table I illustrates the reflex of the financial autonomy on the evolution of salaries in the branches with budgetary autonomy (judiciary, legislature, and public prosecution) in comparison with the federal executive. Between 1994 and 2002 the average salary in the executive branch rose $8.1 \%$ in real terms. In the autonomous branches, salaries had an average real growth of $89 \%$. As at the municipal level there are no judiciaries and no public prosecution, the legislature prevails as the only branch with financial autonomy. ${ }^{20}$

18 Alesina, Hausmann, Holmmes and Stein (1999) discuss the theoretical aspects of this point.

19 About the veto power of the legislatures in the Brazilian political system see Samuels (2001).

20 The municipal (as well as state) legislatures became a recognized locus of capture of public resources. The first amendment that was approved for the 1988 Constitution (Constitutional Amendment $\mathrm{N}^{\circ} 1 / 1992$ ) was precisely the one that limited the salaries of councilmen and state deputies. Subsequently, three other amendments were approved with the purpose of refraining the expenditure of the city council. 
Table I - Real average wage increase of federal civil servants for different government branches: 1995-2002

\begin{tabular}{lc}
\hline Branches & Real average wage increase $(\%)^{*}$ \\
\hline Executive & 8.1 \\
Legislative (A) & 35.4 \\
Judiciary (B) & 113.7 \\
Public Prosecution (C) & 89.7 \\
Total for autonomous branches $(\mathrm{A}+\mathrm{B}+\mathrm{C})$ & 89.0 \\
\hline
\end{tabular}

Source: Planning and Budget Ministry. (*) Deflated by a Price Consumer. Index (IPCA - IBGE).

Graph I shows the federal legislative expenditure versus the sum of the federal expenditure in all the other government areas, as a percentage of the GDP. First of all, one can clearly see that the legislative expenditure rises faster than the others: the first goes from $0,11 \%$ to $0,22 \%$ of the GDP over the years considered in the graph, while the total expenditure decreases from $8,7 \%$ to $6,4 \%$ of the GDP. Moreover, the legislative expenditure skyrocketed from 1985 onwards, just after the end of the military government. Exactly at this moment the legislative recovered its power to block the propositions made by the executive. Another jump in the legislative expenditure is observed in 1988, when a new constitution established a shield against expenditure cuts in the legislative. From 2000 onwards, the total federal expenditure decreased sharply, due to a program of fiscal adjustment, but the Graph shows that the legislative expenditure was much less affected.

Graph I - Legislative expenditure vs. other functions expenditure of the Brazilian federal government (1980-2003) - \% of GDP

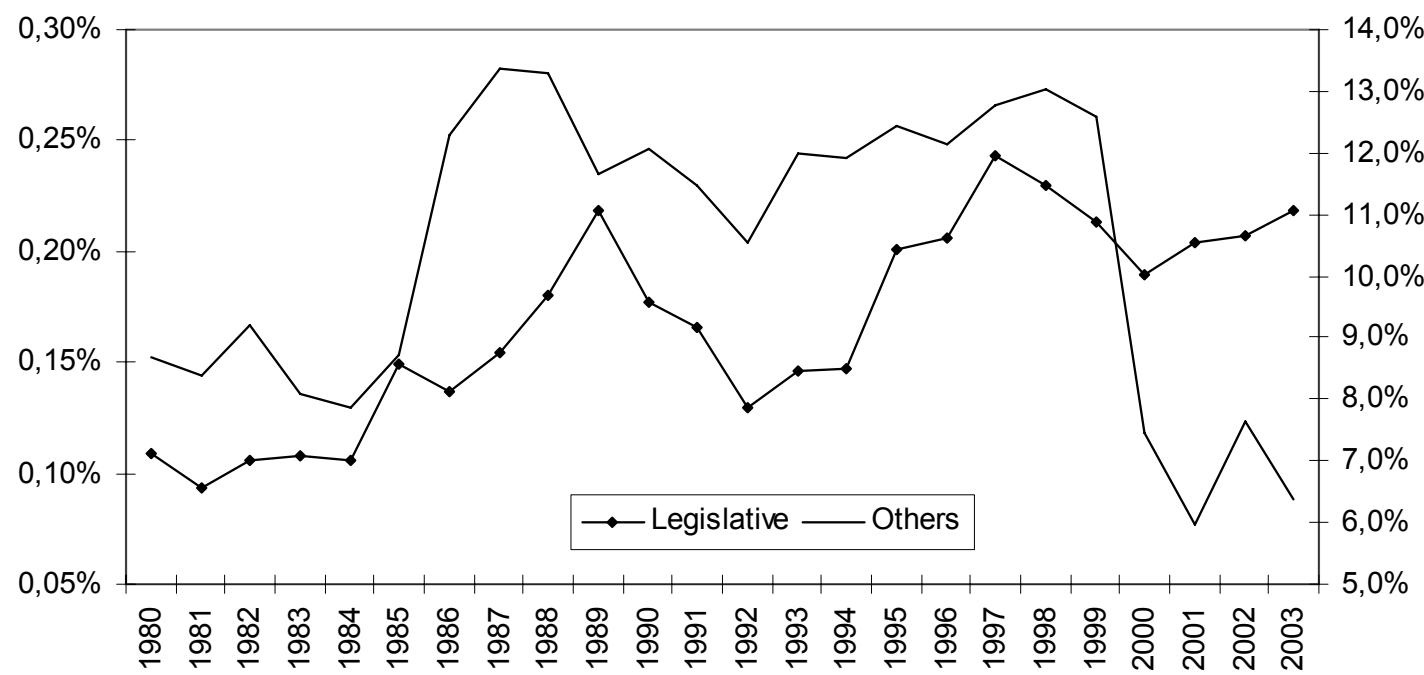

Source: Brazilian National Treasure Department (STN). Obs: the other government functions are: defense, foreign affairs, police, health, human rights, culture, employment, urban \& sanitary works, environment, science \& technology, agriculture, industry, trade \& services, communication, energy, transportation, sports \& leisure. Two government functions were not included due to the persistency of their expenditure over the years: social security and interest payments. 
In 1996, 35\% of the municipalities had expenditures with city councils superior to their collected revenue. In other words, these municipalities used all their local collection plus part of the received transfers to finance the local legislature. Nineteen percent of the local governments spent more with legislature than with housing and urbanism. ${ }^{21}$

From the econometric point of view there is also an advantage in adopting the legislative expenditure as measure of capture. First, it would be very exotic to have a median voter who, once the basic operating needs of the local legislature were met, would rather give a salary raise to the councilmen instead of, so to speak, increasing the paving of streets or reducing local taxes. Second, the Federal Constitution standardizes, for the whole country, the political and constitutional attributions of the municipalities and their city councils. Therefore, there is no possibility that one city council spend more than the others because of a broader set of policy responsibilities. For this reason, it is possible to suppose that (conditioned to the control variables) the city councils that spend above the national average are being vehicles of capture.

Problems related to fixed costs, scale gains, and complexity of urban problems in metropolitan areas, which may result in different costs for legislatures in different cities, may be properly treated by introducing control variables in the estimations, such as the size of the municipal population, the number of councilmen, or the urbanization degree.

For all the reasons presented above, the paper uses the municipal legislative expenditure as the dependent variable in the estimation of equation $(1) .^{22}$

\section{ESTIMATIONS}

The database constitutes of a cross-section of 3,914 municipalities for which there are available data. The reference year is 1996. Not all the data are available for the 3,914 municipal districts, so the number of observations effectively used in the regressions ranges from 3,423 to 3,648 which represent from $69 \%$ to $73 \%$ of the 4,974 municipalities existing in that year.

The following control variables are used in order to capture specific profiles of municipalities: population (POP), square population (POP2), geographical area (AREA), square area (AREA2), number of councilmen (CONS), square number of councilmen (CONS2), dummy for municipality belonging to the periphery of a metropolitan area (METROPO), population distribution by age group, ${ }^{23}$ dummies of geographical region (that indicate if the municipality belongs to the Northern $(\mathrm{N})$, Northeastern (NE), Middle Western (CO), Southern (S) or Southeastern (SE) region), dummies for the state capitals (CAP), dummies for new municipalities created after 1988 (NEW), ${ }^{24}$ percentage of urban population in the total population (URB). Data sources are described in Table II, which also presents descriptive statistic.

21 Source: National Treasury Department.

22 Legislative expenditure is defined by the Brazilian National Treasury Department as comprising all the current and capital expenditure made by the legislative power.

23 LF0-4 indicates the number of residents with ages between zero and four, and, with similar definition, there are the LF5-14, LF15-29, LF30-49 and LF50 variables, this last one indicating the population aged 50 or more.

24 New municipalities, shortly after their creation, tend to present high expenditure for the physical installation of the local government. 
Table II - Descriptive statistics

\begin{tabular}{|c|c|c|c|c|c|c|}
\hline & Measurement unit & Mean & Std deviation & Min & Max & $\mathrm{N}^{0}$ of observations \\
\hline LEG $^{(1)}$ & $\$$ & 463,079 & $2,985,496$ & 10,756 & $152,415,416$ & 3648 \\
\hline TAXREV ${ }^{(1)}$ & $\$$ & $2,281,572$ & $44,700,444$ & 0 & $2,614,611,422$ & 3648 \\
\hline FPM $^{(1)}$ & $\$$ & $1,887,077$ & $2,866,242$ & 27,358 & $61,590,256$ & 3523 \\
\hline ICMS $^{(1)}$ & $\$$ & $3,136,173$ & $27,850,936$ & 824 & $1,522,403,622$ & 3523 \\
\hline $\mathrm{LCl}^{(2)}$ & indices 0 to 1 & 0.63 & 0.12 & 0.33 & 0.86 & 3648 \\
\hline ROYALTIES ${ }^{(3)}$ & dummy & 0.01 & 0.08 & 0 & 1 & 3648 \\
\hline METROPO (4) & dummy & 0.09 & 0.28 & 0 & 1 & 3648 \\
\hline$N^{(4)}$ & dummy & 0.03 & 0.16 & 0 & 1 & 3648 \\
\hline$N E^{(4)}$ & dummy & 0.31 & 0.46 & 0 & 1 & 3648 \\
\hline $\mathrm{CO}^{(4)}$ & dummy & 0.09 & 0.28 & 0 & 1 & 3648 \\
\hline $\mathrm{SE}{ }^{(4)}$ & dummy & 0.35 & 0.48 & 0 & 1 & 3648 \\
\hline$S^{(4)}$ & dummy & 0.23 & 0.42 & 0 & 1 & 3648 \\
\hline AREA ${ }^{(4)}$ & $\mathrm{Km}^{2}$ & 1,055 & 2,257 & 4 & 48,815 & 3641 \\
\hline URB ${ }^{(4)}$ & $\%$ & 59.2 & 22.7 & 3.15 & 100 & 3648 \\
\hline POP (4) & \# of inhabitants & 32,868 & 186,189 & 834 & $9,839,066$ & 3648 \\
\hline $\operatorname{CONS}^{(5)}$ & \# of councilmen & 11.4 & 3.47 & 9 & 55 & 3569 \\
\hline NEW ${ }^{(4)}$ & Dummy & 0.02 & 0.15 & 0 & 1 & 3648 \\
\hline CAP (4) & dummy & 0.005 & 0.07 & 0 & 1 & 3648 \\
\hline CUREXP (1) & $\$$ & $8,788,744$ & $78,901,371$ & 522,091 & $4,429,356,675$ & 3648 \\
\hline$L F-0-4^{(4)}$ & \# of inhabitants & 3,827 & 18,491 & 55 & 954,716 & 3648 \\
\hline LF5-14 (4) & \# of inhabitants & 6,993 & 34,120 & 177 & $1,760,135$ & 3648 \\
\hline LF15-29 (4) & \# of inhabitants & 9,224 & 53,421 & 213 & $2,792,981$ & 3648 \\
\hline LF30-49 (4) & \# of inhabitants & 8,489 & 53,675 & 217 & $2,867,005$ & 3648 \\
\hline LF50 (4) & \# of inhabitants & 4,967 & 29,946 & 136 & $1,625,088$ & 3569 \\
\hline
\end{tabular}

Sources: (1) Brazilian National Treasure Department (STN), (2) United Nations Development Program, IPEA, IBGE, FJP (1998), (3) Brazilian National Petroleum Agency (ANP), (4) Brazilian Institute of Geography and Statistics (IBGE), (5) Brazilian Electoral Superior Court (TSE).

Table III shows the results of estimations in ordinary least squares. Given the possibility of heteroscedasticity, since the municipalities range from very small ones (less than 1,000 inhabitants) to megalopolis with more than 10 million inhabitants, White's (1980) covariance matrix estimator is used. ${ }^{25}$ The data are used in logarithmic form, which makes it easier to read the coefficients as elasticities. The values below the estimated coefficients represent the probability of the non-rejection of the hypothesis that the coefficient is equal to zero in a Wald test (or asymptotic " $\mathrm{t}$ " test).

25 White's heteroscedasticity test to the equation (1) rejects the homoscedasticity null hypothesis with a probability of $100 \%$. Other usual tests (Breush - Pagan, Goldfeld - Quandt, Glesjer) produced the same result. The consistency of the OLS estimator and the availability of a large sample grants greater reliability to the asymptotic proprieties of the estimator of the coefficients and the estimator of White's matrix. 
Table III - Least square estimations

\begin{tabular}{|c|c|c|c|c|}
\hline & I & II & III & IV \\
\hline Method & OLS & OLS & $2 S L S$ & OLS \\
\hline Dependent variable & LEG & LEG & LEG & CUREXP \\
\hline \multirow[t]{2}{*}{ CONST } & 6.832 & 6.186 & 6.500 & 9.185 \\
\hline & $(0.000)$ & $(0.003)$ & $(0.000)$ & $(0.000)$ \\
\hline \multirow[t]{2}{*}{ POP } & -2.471 & -1.464 & -1.705 & -0.514 \\
\hline & $(0.014)$ & $(0.170)$ & $(0.088)$ & $(0.296)$ \\
\hline \multirow[t]{2}{*}{ POP2 } & 0.061 & 0.060 & 0.060 & 0.052 \\
\hline & $(0.000)$ & $(0.000)$ & $(0.000)$ & $(0.000)$ \\
\hline \multirow[t]{2}{*}{ AREA } & -0.225 & -0.117 & -0.116 & -0.023 \\
\hline & $(0.000)$ & $(0.007)$ & $(0.055)$ & $(0.507)$ \\
\hline \multirow[t]{2}{*}{ AREA2 } & 0.017 & 0.011 & 0.010 & 0.001 \\
\hline & $(0.000)$ & $(0.033)$ & $(0.027)$ & $(0.626)$ \\
\hline \multirow[t]{2}{*}{ CONS } & 1.896 & 1.272 & 1.226 & 0.315 \\
\hline & $(0.002)$ & $(0.051)$ & $(0.057)$ & $(0.389)$ \\
\hline CONS2 & $\begin{array}{l}-0.291 \\
\end{array}$ & $\begin{array}{r}-0.179 \\
\end{array}$ & $\begin{array}{r}-0.169 \\
\end{array}$ & $\begin{array}{r}-0.040 \\
-0581)\end{array}$ \\
\hline \multirow[t]{2}{*}{ URB } & $\begin{array}{r}0.010) \\
-0.980\end{array}$ & -1.247 & -1.215 & -0.471 \\
\hline & $(0.000)$ & $(0.000)$ & $(0.000)$ & $(0.000)$ \\
\hline \multirow{2}{*}{ URB2 } & 0.161 & 0.196 & 0.190 & 0.007 \\
\hline & $(0.000)$ & $(0.000)$ & $(0.000)$ & $(0.000)$ \\
\hline \multirow[t]{2}{*}{ LF0-4 } & 0.265 & 0.021 & 0.024 & -0.043 \\
\hline & $(0.019)$ & $(0.867)$ & $(0.839)$ & $(0.427)$ \\
\hline \multirow[t]{2}{*}{ LF5-14 } & 0.630 & 0.536 & 0.621 & 0.149 \\
\hline & $(0.019)$ & $(0.052)$ & $(0.017)$ & $(0.235)$ \\
\hline \multirow[t]{2}{*}{ LF15-29 } & 0.124 & 0.028 & 0.097 & -0.245 \\
\hline & $(0.662)$ & $(0.921)$ & $(0.734)$ & $(0.069)$ \\
\hline \multirow{2}{*}{ LF30-49 } & 0.322 & -0.035 & -0.043 & -0.001 \\
\hline & $(0.263)$ & $(0.904)$ & $(0.876)$ & $(0.993)$ \\
\hline \multirow[t]{2}{*}{ LF50 } & 0.144 & -0.086 & -0.034 & -0.082 \\
\hline & $(0.392)$ & $(0.623)$ & $(0.838)$ & $(0.328)$ \\
\hline \multirow[t]{2}{*}{ N } & 0.311 & & & -0.053 \\
\hline & $(0.000)$ & & & $(0.103)$ \\
\hline \multirow[t]{2}{*}{ NE } & 0.372 & & & 0.111 \\
\hline & $(0.000)$ & & & $(0.000)$ \\
\hline \multirow[t]{2}{*}{$\mathrm{CO}$} & 0.351 & & & -0.010 \\
\hline & $(0.000)$ & & & $(0.552)$ \\
\hline s & 0.040 & & & -0.001 \\
\hline & $(0.138)$ & & & $(0.918)$ \\
\hline CAP & -0.325 & -0.288 & -0.321 & -0.249 \\
\hline & $(0.037)$ & $(0.065)$ & $(0.030)$ & $(0.020)$ \\
\hline NEW & 0.022 & 0.057 & 0.055 & 0.014 \\
\hline & $(0.694)$ & $(0.289)$ & $(0.343)$ & $(0.681)$ \\
\hline METROPO & 0.101 & 0.078 & 0.068 & -0.003 \\
\hline & $(0.003)$ & $(0.016)$ & $(0.031)$ & $(0.849)$ \\
\hline ROYALTIES & 0.514 & 0.233 & 0.214 & 0.099 \\
\hline & $(0.000)$ & $(0.023)$ & $(0.037)$ & $(0.110)$ \\
\hline $\operatorname{TAXREV}\left(\alpha_{1}\right)$ & 0.042 & 0.038 & 0.081 & 0.083 \\
\hline & $(0.000)$ & $(0.000)$ & $(0.009)$ & $(0.000)$ \\
\hline ICMS $\left(\alpha_{2}\right)$ & 0.265 & 0.263 & 0.255 & 0.248 \\
\hline & $(0.000)$ & $(0.000)$ & $(0.000)$ & $(0.000)$ \\
\hline FPM $\left(\alpha_{3}\right)$ & 0.424 & 0.439 & 0.436 & 0.263 \\
\hline & $(0.000)$ & $(0.000)$ & $(0.000)$ & $(0.000)$ \\
\hline LCI & -0.445 & -0.372 & -0.488 & 0.121 \\
\hline & $(0.002)$ & $(0.008)$ & $(0.003)$ & $(0.098)$ \\
\hline Adjusted $\mathrm{R}^{2}$ & 0.810 & 0.834 & 0.835 & 0.951 \\
\hline \# of used observations & 3.417 & 3.417 & 3.685 & 3.685 \\
\hline Wald Tests : Prob $\mathrm{H}_{0}$ : & & & & \\
\hline$\alpha_{1}=\alpha_{2}$ & 0.000 & 0.000 & 0.000 & 0.000 \\
\hline$\alpha_{1}=\alpha_{3}$ & 0.000 & 0.000 & 0.000 & 0.000 \\
\hline$\alpha_{2}=\alpha_{3}$ & 0.066 & 0.036 & 0.000 & 0.775 \\
\hline
\end{tabular}


The first column shows the results for an OLS estimation. The estimated coefficients are in compliance with the hypotheses formulated in section 2. First, the elasticity of the legislative expenditure (capture) in relation to the tax revenue (TAXREV) is quite low (0.04) when compared to the elasticity in relation to the ICMS transfers (0.26). This, in turn, is much inferior to the elasticity of the capture in relation to the FPM transfers (0.42). All the coefficients are significant at less than $1 \%$. A Wald test presented at the bottom of Table 1 shows that the probabilities of the hypotheses $\alpha_{1}=\alpha_{2}, \alpha_{1}=\alpha_{3}, \alpha_{2}=\alpha_{3}$ are quite low. Only the hypothesis $\alpha_{2}=\alpha_{3}$ presents a probability higher than $5 \%$.

Therefore, the data are coherent with the hypotheses that the capture is directly related to the degree of fiscal illusion or the voter's bargaining power in relation to each type of revenue $\left(\alpha_{3}>\alpha_{2}>\alpha_{1}\right)$.

Second, the legislative expenditure falls $4.4 \%$ for every $10 \%$ increase in the life conditions index (LCI) of the municipality. Other results, relating to control variables, seem coherent with the hypothesis of inverse relation between life conditions and capture. The dummies for geographical regions with greater poverty concentration (North - N, Northeast - NE and the Middle West $\mathrm{CO})$ present an average legislative expenditure that surpasses that of the Southeast region. In addition, the municipalities of the metropolitan periphery (METROPO) - localities where there is great poverty concentration - also present dummies with a positive sign, $15 \%$ above the average.

Third, the municipalities that are over-financed by ROYALTIES present legislative expenditure more than $50 \%$ above the average. So, it seems coherent with the hypothesis that over-financed municipalities are more exposed to capture.

Column II presents the same OLS estimation as column I, replacing the regions dummies by states dummies. The 21 state dummy coefficients are not reported. The qualitative results of Table I do not change. Two remarks, however, must be made. First, the estimated coefficient for ROYALTIES fell from 0.51 to 0.23 . This happened because two states concentrate $56 \%$ of all municipalities that receive royalties: Rio de Janeiro and Rio Grande do Norte. It is not a coincidence that the dummies of these states presented the highest coefficients among the state dummies. Second, the Wald test on the hypothesis $\alpha_{2}=\alpha_{3}$, which in the estimation in Column I presented a probability of $6,6 \%$, now shows a probability of only $3,6 \%$. This reinforces the acceptance of the proposed relation $\alpha_{3}>\alpha_{2}>\alpha_{1}$.

In Column III the possibility of the tax revenue being an endogenous variable is taken into consideration, since the decision of how much to capture and how much to tax is made in the same arena (the municipal political enviroment). For this reason, a system of 2 equations through a twostage least squares method was estimated. Table III presents only the main equation. The estimated coefficients and the instruments used to estimate the tax revenue are described in Annex I.

The punctual estimate of the elasticity of the legislative expenditure in relation to the tax revenue increased significantly from 0.04 in the previous estimations to 0.08 . But the elasticity of the transfers was still higher $(\mathrm{FPM}=0.44$ and ICMS $=0.25)$, maintaining the relation $\alpha_{3}>\alpha_{2}>\alpha_{1}$. Wald tests still rejected the hypotheses $\alpha_{1}=\alpha_{2}, \alpha_{1}=\alpha_{3}, \alpha_{2}=\alpha_{3}$. The other coefficients of interest did not change.

One may say that the coefficient signs showed in columns I to III are highly expected and should come as no surprise since the more money there is, the more will be spent on all kinds of expenditure, including legislative expenditure. To show that the legislative expenditure (highly influenced by capture behavior) has a different profile from the total expenditure, Column IV shows the estimations when the total current expenditure (and not only the legislative expenditure) is used as a dependent variable. 
The current expenditure, unlike the legislative expenditure, is positively correlated with the life conditions index (LCI). Municipalities with high LCI are more developed, have higher fiscal revenue and, as a result, have higher total government expenditure. However, in the case of legislative expenditure, capture inverts this relationship. Poorer municipalities, in spite of having lower fiscal revenue, put more money into the local councils.

The elasticities of ICMS and FPM also confirm that the total current expenditure differs from the legislative expenditure. When the total current expenditure is the dependent variable, the elasticity of the ICMS and FPM transfers are statistically equal (as confirmed by the Wald test of the hypothesis $\alpha_{2}=\alpha_{3}$ ), not repeating the phenomenon observed for the legislative expenditure in which the FPM elasticity appears as much higher.

Furthermore, the coefficient of ROYALTIES is much lower for the total current expenditure (column IV) than for the legislative expenditure (columns I to III), and significant only at $11 \%$. This result reinforces the idea that overfinancing stimulates the increase of capture (legislative expenditure) more than the increase of total expenditure.

The estimation in OLS may not be adequate when dealing with municipal data, due to the possible existence of spatial dependence. Estimations controlling for this effect - non reported were run. Four sub-samples of non-neighboring municipalities were sorted, and the OLS model run for each of them, as proposed by Anselin (1987). There was no qualitative change in relation to the results of Table III, so that the spatial dependence does not seem to affect the results. The model was also estimated separately for each region of the country and the qualitative results non-reported - did not change. ${ }^{26}$

The model was also estimated by using a panel data for the years 1998 to 2000, controlling for year and fixed effects. ${ }^{27}$ In this option the coefficients associated to immutable variables in time (cities that receive ROYALTIES) or to those for which there is information available for a single year (life condition index - LCI) could not be observed. For this reason the analysis is restricted to testing if $\alpha_{3}>\alpha_{2}>\alpha_{1}$.

In all, except the last, columns of Table IV the data are in logarithmic form. The asymptotic " $\mathrm{t}$ " test is shown in parentheses, under the coefficient value. In the first column, no control variable is used. In the second column, the control variable is the total current expenditure. In the third and fourth columns, the controls are respectively for the total current revenue and the revenues other than the tax revenue, the FPM transfers and ICMS transfers. In all these estimations the expected relation $\alpha_{3}>\alpha_{2}>\alpha_{1}$ is observed. There is only one estimation (Column II) in which it is not possible to reject the hypothesis $\alpha_{1}=\alpha_{2}$. In the fifth column, a linear model is estimated, in contraposition to the log-linear models of the other columns: once again the order $\alpha_{3}>\alpha_{2}>\alpha_{1}$ is checked.

26 See Mendes (2002) for a detailed analysis of these estimations.

27 The administrative and territorial divisions of the Brazilian municipalities are revised every 4 years. In the first year of office of mayors and councilmen the new municipal districts, legally created during the last four years are installed, redrawing the borders of the existing municipal districts. For this reason, the data are comparable only within periods of 4 years, corresponding to the office period of the mayor. In the first year the expenditure of the new municipal districts are atypical, characterized by the physical installation procedures of the buildings and furniture of the administration. For this reason, the panel takes a period from the second (1998) to the forth (2000) year of the mayors' mandate. 
Table IV - Panel data controlling for fixed effects: 1998-2000

\begin{tabular}{|c|c|c|c|c|c|}
\hline & 1 & $\|$ & III & IV & V \\
\hline \multirow[t]{2}{*}{ CONST } & 4.836 & 1.404 & 3.563 & 4.300 & 89392 \\
\hline & $(0.000)$ & $(0.000)$ & $(0.000)$ & $(0.000)$ & $(0.000)$ \\
\hline \multirow[t]{2}{*}{ CUREXP } & & 0.566 & & & 0.027 \\
\hline & & $(0.000)$ & & & $(0.000)$ \\
\hline \multirow[t]{2}{*}{ CURREV } & & & 0.269 & & \\
\hline & & & $(0.000)$ & & \\
\hline \multirow[t]{2}{*}{ OTHERREV } & & & & 0.067 & \\
\hline & & & & $(0.000)$ & \\
\hline \multirow[t]{2}{*}{ TAXREV } & 0.035 & 0.015 & 0.024 & 0.032 & -0.013 \\
\hline & $(0.000)$ & $(0.031)$ & $(0.001)$ & $(0.000)$ & $(0.000)$ \\
\hline \multirow[t]{2}{*}{ ICMS } & 0.130 & 0.036 & 0.085 & 0.126 & 0.005 \\
\hline & $(0.000)$ & $(0.009)$ & $(0.000)$ & $(0.000)$ & $(0.004)$ \\
\hline \multirow[t]{2}{*}{ FPM } & 0.360 & 0.103 & 0.212 & 0.336 & 0.068 \\
\hline & $(0.000)$ & $(0.000)$ & $(0.000)$ & $(0.000)$ & $(0.000)$ \\
\hline$R^{2}$ within & 0.20 & 0.25 & 0.21 & 0.20 & 0.36 \\
\hline$R^{2}$ between & 0.80 & 0.84 & 0.83 & 0.81 & 0.90 \\
\hline $\mathrm{R}^{2}$ overall & 0.79 & 0.83 & 0.82 & 0.80 & 0.89 \\
\hline \# of used observ. & 9791 & 9791 & 9791 & 9791 & 10137 \\
\hline \# of groups & 3319 & 3319 & 3319 & 3319 & 3379 \\
\hline \multicolumn{6}{|l|}{ WALD TESTS } \\
\hline$\alpha_{1}=\alpha_{2}$ & 0.000 & 0.620 & 0.000 & 0.000 & 0.000 \\
\hline$\alpha_{1}=\alpha_{3}$ & 0.000 & 0.000 & 0.000 & 0.000 & 0.000 \\
\hline$\alpha_{2}=\alpha_{3}$ & 0.000 & 0.008 & 0.000 & 0.000 & 0.000 \\
\hline
\end{tabular}

Obs: Year dummies non-reported

\section{CONCLUSIONS}

The estimations show that the theoretical propositions about capture are not rejected in the Brazilian federalism context. The fiscal transfers constitute a type of revenue more subject to capture than the local tax revenue, which is in accordance with the theoretical models of fiscal illusion and bargaining power. In addition, the transfers based on the derivation principle (ICMS) are less prone to capture than the transfers based on formulas of distribution (FPM), which also reinforces those two models. Capture is more intense in the poorest communities. Poorly designed mechanisms of transfer distribution (due to technical difficulties or political pressures) that imply in over-financing of some municipalities stimulate capture. Results do not change when estimations are run separately for each geographical region nor when controlled for spatial dependence and fixed effects. 
The results point to some normative propositions aimed at preventing capture and improving the efficiency of the public goods provision in a federation. First, the fact that capture is more intense in poorer areas is a challenge to policy makers devoted to poverty reduction policies in a federal country, since these policies (public education and health, food stamps, job training etc.) are usually delivered by local governments with federal funds. If capture of the money transferred to local governments is more intense in poorer areas, decentralized poverty reduction policies will be less effective exactly in the regions where they are most needed. It is necessary, therefore, to be concerned with capture when designing the financing and delivery mechanisms of those policies. Pumping money into poor town budgets is not a sufficient condition to reduce poverty.

Second, it is important to avoid the over-financing phenomenon. This implies that the design of an intergovernamental transfer system must be careful not to give excessive transfers to some groups of municipalities. The case studied in this paper is that of municipalities that receive royalties from the federal oil agency (ANP). The huge amount of money paid to these towns is being spent on exotic "public goods" such as the sponsorship of private football teams, as shown in the quotation at the beginning of this paper.

The two points presented above (over-financing and poverty) are sometimes related, since it is common to think that a good way to reduce poverty in small backward rural areas is to increase the fiscal transfers to their town halls. This may result in a big amount of money in the hands of local politicians, in small communities that do not have scale to offer a wide range of public services. Furthermore, the poor people living in these towns do not have knowledge, ability or money to finance an organization to lobby for the use of public funds on their behalf. The result will probably be the capture of the additional money received by the poor towns. ${ }^{28}$

Third, since the paper showed that local tax is less subject to capture, it is important to provide municipalities with technical assistance to improve their tax collection. At the same time, it is necessary to reduce the great participation of formula-based transfers in the local financing, which is a clear feature of low and mid income federations, particularly of Brazil.

\section{ANNEX I}

In order to obtain an instrument for the variable TAXREV, some variables were used in a Two-Stage Least Squares estimation of a system of equation. This annex describes these variables and the reasons why each variable was used.

First of all, the variables that are subject to political influence were not used as instruments, because they are probably correlated with our proxy for capture (legislative expenditure), as this is itself a variable influenced by local political decisions. Therefore, three variables were not used: ICMS (because $1 / 4$ of it is distributed among municipalities based on state government criteria), the number of councilmen and NEW (because the decision of creating a new municipality or remaining as part of an old one is typically a political one). It is important to note that including these variables does not change the qualitative results presented below.

Second, variables that may be correlated with the local tax revenue and are predefined or do not change quickly (therefore they are not caused by LEG or TAXREV) were used as instruments. This is the case of the following variables: POP, AREA, URB, state dummies, METROPO, ROYALTIES, FPM, CAP and LCI.

28 Gasparini and Ramos (2004) and Gasparini and Melo (2004) present methodologies to estimate efficiency in the use of public resources by municipalities. This kind of instrument may be useful in the reform of the Brazilian fiscal transfer framework, specially to reduce the over-financing of some municipalities. 
Third, a new set of variables correlated with the local tax revenue was included to increase the efficiency of the instrumental variable estimated. These variables and their sources are the following:

Tourism (TOUR): a dummy variable with value 1 for the municipalities that are considered tourist sites. This kind of municipality usually collects more taxes, paid by non-residents when visiting the city. Source: EMBRATUR - Brazilian Tourist Enterprise.

Number of bank branches (AGBAN): a proxy of the level of economic activity in the municipality. Since there are many municipalities with no bank branches, the variable was transformed as $\log (1+$ AGBAN). Source: IBGE - Brazilian Institute of Geography and Statistics.

Mean deposit value per bank branch (APLIC): a proxy of the level of economic activity in the municipality. Since there are many municipalities with no bank branches, the variable was transformed as $\log (1+$ APLIC). Source: IBGE - Brazilian Institute of Geography and Statistics.

Number of firms with no canceled registration in the municipality (FIRMS): another proxy for the local economic activity. Source: IBGE - Brazilian Institute of Geography and Statistics.

Number of employees of local firms (PERSON): another proxy for the local economic activity. Source: IBGE - Brazilian Institute of Geography and Statistics.

Number of real estate agencies in the municipality (REALST): a proxy for the importance of the real estate market and the value of property tax collected. Source: IBGE - Brazilian Institute of Geography and Statistics.

The estimated coefficients and the probability of the coefficient being equal zero in a t- test, using the log of variables, are presented below (state dummy variables are non-reported):

\begin{tabular}{ccccccccc}
\hline$C$ & POP & AREA & URB & CAP & METROPO & ROYALTIES & FPM & LCI \\
\hline 5.163 & 0.565 & 0.059 & 0.142 & 0.408 & 0.195 & 0.500 & -0.080 & 2.284 \\
$(0.000)$ & $(0.000)$ & $(0.001)$ & $(0.001)$ & $(0.076)$ & $(0.000)$ & $(0.004)$ & $(0.252)$ & $(0.000)$ \\
\hline
\end{tabular}

\begin{tabular}{cccccc}
\hline TOUR & PERSON & AGBAN & APLIC & FIRMS & REALST \\
\hline 0.402 & 0.285 & 0.099 & 0.001 & 0.071 & 0.175 \\
$(0.000)$ & $(0.000)$ & $(0.049)$ & $(0.849)$ & $(0.092)$ & $(0.000)$ \\
\hline
\end{tabular}

\section{REFERENCES}

Afonso, J. R.; Mello, L. Brazil: an evolving federation. Annals of the IMF Conference on Fiscal Decentralization. Washington-DC: International Monetary Fund, 2000.

Ahmad, E.; Craig, J. Intergovernmental transfers. In: Ter-Minassian, T. (ed.), Fiscal federalism in theory and practice. Washington D.C: International Monetary Fund, 1997, p. 73-107.

Alesina, A.; Hausmann, H.; Holmmes, R.; Stein, E. Budget institutions and fiscal performance in Latin America. Journal of Development Economics, v. 59, p. 233-253, August 1999. 
Alm, J. Intergovernmental grants and social welfare. Public Finance/Finances Publiques, v. 38, n. 3, p. 377-397, 1983.

Anselin, L. Spatial econometrics: methods and models. London: Kluwer Academic Publishers, 1987.

Bardhan, P.; Mookherjee, D. Capture and governance at local and national levels. American Economic Review, v. 90, n. 2, p. 135-139, 2000.

Bird, R. Threading the fiscal labyrinth: some issues in fiscal decentralization. National Tax Journal, v. 46, n. 2, p. 207-227, 1993.

Chernick, H. A. An economic model of the distribution of project grants. In: Mieszkowski, P.; Oakland, W. H. (eds.), Fiscal federalism and grants-in-aid. Washington DC: The Urban Institute, 1979, p. 5573.

Gasparini, C.; Melo, C. S. L. Eqüidade e eficiência municipal: uma avaliação do Fundo de Participação dos Municípios. In: Finanças Públicas: VIII Prêmio Tesouro Nacional. Brazilian Ministry of Finance, 2004.

Gasparini, C.; Ramos, F. S. Incentivos à eficiência na descentralização fiscal brasileira: o caso do FPM no Estado de São Paulo. Pesquisa e Planejamento Econômico, v. 34, n. 1, 2004.

Giambiagi, F.; Além, A. C. Finanças públicas: teoria e prática no Brasil. $2^{\text {nd }}$ Edition. Ed. Campus, 2001.

Gramlich, E. M. Intergovernmental grants: a review of the empirical literature. In: Oates, W. E. (ed), The political economy of fiscal federalism. Lexington, M. A. Lexington Press, 1977.

Gramlich, E. M.; Galper, H. State and local behavior and federal grant policy. Brookings Papers n. 1, 1973.

Grossman, P. J. A political theory of intergovernmental grants. Public Choice, v. 78, p. 295-303, 1994.

Hamilton, J. H. The flypaper effect and deadweight loss from taxation. Journal of Urban Economics, v. 19, n. 2, p. 148-155, 1986.

Hemming, R.; Spahn, P. B. European integration and the theory of fiscal federalism. In: Ter-Minassian, T.; Blejer, M. (eds.), Macroeconomic dimension of public finance: essays in honor of Vito Tanzi. Washington D.C: International Monetary Fund, 1997, p. 110-130.

Hommes, R. Conflicts and dilemmas of decentralization. The World Bank Research Observer. Annual Conference Supplement, 1995, p. 331-59.

Inman, R. P. Federal assistance and local services in the United States: the evolution of a new federalist fiscal order. In: Rosen, H. (ed.), Fiscal federalism: quantitative studies. Chicago-Ill: University of Chicago Press, 1988.

Inman, R. P; Rubinfeld, D. L. Designing tax policies in federalist economies: an overview. Journal of Public Economics, v. 60, p. 307-334, 1996.

. Rethinking federalism. Journal of Economic Perspectives, v. 11, n. 4, p. 43-64, 1997.

United Nations Development Program and IPEA and IBGE and FJP. Atlas do desenvolvimento humano no Brasil. CD-ROM, 1998.

Kornai, J. The soft budget constraint. Kyklos, v. 39, n. 1, p. 3-30, 1986.

Kraemer, M. Intergovernmental transfers and political representation: empirical evidence from Argentina, Brazil and México. Inter-American Development Bank, Working Paper 345, 1997.

Laband, D. N. The private interest in public redistribution: a public choice view of the geographic distribution of federal funds. Public Choice, v. 49, p. 117-125, 1986.

McLure Jr., C. Topics in the theory of revenue assignment: gaps, traps and nuances. In: Ter-Minassian, T.; Blejer, M. (eds.), Macroeconomic dimension of public finance: essays in honor of Vito Tanzi. Washington D.C: International Monetary Fund, 1997, p. 94-109.

Mendes, M. Descentralização fiscal baseada em transferências e captura de recursos públicos nos municípios brasileiros. 2002. Doctoral Thesis, University of São Paulo. 
Moffit, R. A. The effects of Grants-In-Aid on State and local expenditures: the case of AFDC. Journal of Public Economics, v. 23, p. 279-305, 1984.

Musgrave, R. Who should tax, where, and what? In: Oates, W. E. (ed.), The economics of fiscal federalism and local finance. Massachusetts: Edward Elgar, 1983, p. 63-80.

Niskanen, W. A. Bureaucracy and representative government. Chicago-Ill.: Aldine-Atherton, 1971.

Oates, W. E. Federalism and government finance. In: Oates, W. E. (ed.), The economics of fiscal federalism and local finance. Massachusetts: Edward Elgar, 1994, p. 10-40.

. Fiscal federalism. New York: Harcourt Brace, 1972.

Persson, T.; Tabellini, G. Political economics: explaining economic policy. MIT Press, 2000.

Prud'homme, R. The dangers of decentralization. World Bank Research Observer, v. 10, n. 02, p. 201-226, 1995.

Reinikka, R.; Svensson, J. Local capture: evidence from a central government transfer program in Uganda. Quarterly Journal of Economics, v. 19, n. 2, p. 679-705, 2004.

Resende, M. Fiscal federalism in Brazil: an empirical investigation. Economia Aplicada, v. 7, n. 1, p. 6382, jan./mar. 2003.

Rezende, F. Federalismo fiscal no Brasil. Revista de Economia Política, n. 15, p. 5-17, 1995.

Samuels, D. Does money matter? Credible commitments and campaign finance in new democracies: theory and evidence from Brazil. 2000. Available at: http://www.polisci.umn.edu/faculty/dsamuels/DoesMoneyMatter.PDF.

. Ambassador of the States: federalism, ambition, and congressional politics in Brazil. Cambridge: Cambridge University Press, 2001.

. Pork barreling is not credit claming or advertising: campaign finance and the sources of the personal vote in Brazil. The Journal of Politics, v. 64, n. 3, p. 845-863, 2002.

Shah, A. The reform of intergovernmental fiscal relations in developing and emerging market economies. Washington- D.C: The World Bank, 1994.

Strumpf, K. S. A predictive index for the flypaper effect. Journal of Public Economics, v. 69, p. 389-412, 1998.

Tanzi, V. Fiscal federalism and decentralization: a review of some efficiency and macroeconomic aspects. Washington, D.C: International Monetary Fund, 1995. Mimeografado.

Ter-Minassian, T. Intergovernamental fiscal relations in a macroeconomic perspective: an overview. In: Ter-Minassian, T. (ed.), Fiscal federalism in theory and practice. Washington D.C.: International Monetary Fund, 1997, p. 3-24.

White, H. A. Heteroscedasticity: consistent covariance matrix estimator and direct test for heteroscedasticity. Econometrica, v. 48, p. 817-838, 1980.

Wyckoff, P. G. A bureaucratic theory of flypaper effects. Journal of Urban Economics, v. 23, p. 115-129, 1988. 